\title{
Childbirth care in Brazil: a critical situation has not yet been overcome. 1999-
} 2013

\author{
Ana Lucia Andrade da Silva 1 \\ Antonio da Cruz Gouveia Mendes 2 \\ Gabriella Morais Duarte Miranda 3 \\ Pedro Miguel dos Santos Neto 4
}

\begin{abstract}
1-4 Centro de Pesquisas Aggeu Magalhães. Fundação Oswaldo Cruz, Pernambuco. Av. Professor Moraes Rego, s.n. Campus da UFPE. Cidade Universitária. Recife, PE, Brasil. CEP: 50.740-465

E-mail: anadasilva78@yahoo.com.br
\end{abstract}

\begin{abstract}
Objectives: to analyze the evolution of childbirth care in Brazil, between 1999-2013.

Methods: a time-series ecological study, using data from Ministry of Health, Brazilian Institute of Geography and Statistics, and Interagency Network of Information for Health. 18 indicators were analyzed related to childbirth and mortality.

Results: there was a reduction in rates of fertility, natality and the total number of births, with increased cesarean surgeries. Growth of prenatal consultation, intensive care beds and reduction of beds in obstetrics sector. The significant growth of caesarean deliveries, prenatal consultation coverage and concentration of births in hospitals occurred simultaneously with the growth: of preventable child deaths by adequate attention, management causes and appropriate delivery, prematurity; low weight; Down's syndrome; and the persistence of maternal deaths due to direct obstetric causes.

Conclusions: persists hegemonic technocratic model of childbirth care without considering the observed changes in the profile of mothers and births, with slow reduction of perinatal and neonatal deaths and maintenance of high maternal mortality demonstrating that the critical situation of delivery care model in Brazil has not, yet, been overcome.
\end{abstract}

Key words Delivery of health care, Maternal and child health, Health status indicators 


\section{Introduction}

The quality of prenatal, childbirth and postpartum care for women is closely related to maternal and child morbidity and mortality. ${ }^{1-2}$ In Brazil, where childbirth care is centered on hospitalization, invasive interventions and excessive use of technology and drugs to speed up labor, avoidable maternal and child deaths are the predominant kind.3-6

Avoidable maternal deaths are defined as direct obstetric maternal deaths resulting from obstetric complications during pregnancy, childbirth or puerperium, owing to interventions, omissions, incorrect treatment or a chain of events deriving from any of these causes. ${ }^{7}$

The causes of avoidable infant death are considered to be totally or partially preventable by effective action by health services accessible at a certain time and place. The avoidability of deaths of children aged under five years of age is analyzed using groups of basic causes as a reference, according to the International Classification of Diseases (ICD). The Brazilian National Health System (SUS) uses the List of Preventable Causes of Deaths proposed by Malta et al., 8 with the following categories: reducible by immunoprevention actions; reducible by adequate care for mother during gestation; reducible by adequate care for mother during childbirth; reducible by adequate care of newborn; reducible by adequate diagnosis and treatment; and reducible by adequate health promotion combined with adequate health care. $8-9$

With a view to making up for these gaps and weaknesses in the childbirth care model, in 2000, the National Health System introduced the Childbirth Humanization Program (PHPN). This sought to promote healthy childbirth and to prevent maternal and perinatal mortality, and ensure improved access, coverage and quality of prenatal supervision, childbirth and puerperium care for mothers and newborns, seen from the point of view of citizenship rights. 10

In the everyday practice of services, however, there are various problems that interfere with the quality of care for women. Health networks are still not consolidated and there is weak integration between prenatal and childbirth care. Access to health services is still difficult, with striking regional and intraregional disparities in the distribution and quality of health services. $3,11,12$

Evaluation of the care provided for women during the pregnancy-puerperium cycle is the subject of great interest in the field. The production of information by way of a Health Status Analysis is thus fundamental for guiding health actions and enabling the identification of needs and priorities, as a way of aiding decision making. 13

Health Information Systems (HIS) are thus valuable tools for planning, organization and evaluation of health services and actions. ${ }^{14}$ However, the quality and reliability of the information produced by these systems are directly influenced by the processes of gathering, recording, processing and producing data. 15

Over the 28-year history of the SUS, successive policies have targeted obstetric and neonatal care as a way of assuring appropriate and high quality care for pregnant women and newborns, with a positive impact on mother and child health indicators. The present study thus aims to examine childbirth care in Brazil in the past fifteen years, according to the profile of births, the characteristics of newborns and avoidable maternal and child mortality, using data from Health Information Systems.

\section{Methods}

An ecological time series study was carried out of the evolution of childbirth care in the country between 1999 and 2013. Secondary data were gathered from official Ministry of Health systems: the Hospital Information System (SIH), the Live Births Information System (Sinasc) and the Mortality Information System (SIM); from the Brazilian Institute of Geography and Statistics (IBGE); and the Interagency Health Information Network (Ripsa).

Sixteen indicators relating to births and deaths were analyzed. The information on childbirth care (number of normal births and percentage of caesarians) came from the SIH (which records only hospitalizations in SUS units); the data on prenatal care (number of women with seven or more consults) were obtained from Sinasc.

The study used absolute and relative frequencies for primaparous women aged up to 15 years and 40 years or more and newborns (NBs) with: Down syndrome, low birth weight (up to $2499 \mathrm{~g}$ ) and premature birth (gestational age up to 36 weeks), grouped according to the age group of mothers (10 19 years; 20 - 39 years; $40-49$ years and 50 and over).

The coefficients for neonatal mortality (number of deaths of children with up to 27 full days of life per $1000 \mathrm{NBs}$ ) and perinatal mortality (number of deaths occurring in the perinatal period - between twenty-two full weeks of gestation and seven full days after birth, per 1000 total births (live births and fetal deaths), were obtained from the SIM. 
The data on total population and number of women of fertile age (10 - 49 years) were calculated on the basis of the IBGE census data and intercensus estimates. 16

The total fecundity rate (mean number of live births per woman, in the 15 - 49 year age group), the raw birth rate (number of live births per 1000 inhabitants, in the resident population) and maternal death rate (number of maternal deaths per 100,000 live births of women residents) were obtained directly from the indicators matrix produced by Ripsa. ${ }^{17}$

Maternal death was defined as the death of a woman during gestation or up to 42 days after the end of gestation, regardless of duration or location of pregnancy, caused by any factor related to or exacerbated by pregnancy or by measures taken in relation to it. 7

Information on the avoidability of infant deaths and the causes of maternal mortality were taken from the Maternal and Child Mortality Monitoring Panel, the General Coordination for Information and Epidemiological Analyses (CGIAE/SVS/MS).

Using the List of Causes of Deaths Avoidable by Brazilian National Health System Interventions proposed by Malta et al.,8 the following were selected as causes of avoidable infant deaths: those reducible by adequate care during gestation and childbirth; by adequate care of the fetus and newborn; by health promotion; and unavoidable deaths. The causes of maternal mortality included: direct obstetric causes (hypertension, hemorrhage, puerperal infection and miscarriage); and indirect obstetric causes (deaths from AIDs and disorders of the circulation, complicating pregnancy, childbirth and puerperium). ${ }^{7}$

For each of the 16 indicators analyzed, the Proportional Variation (PV) Coefficient was calculated using the equation: $\mathrm{PV}=[$ (Indicator last year/Indicator first year) - 1] x 100 .

Analysis of the tendency of the indicators over time was carried out using simple linear regression models. All decisions were taken based on a level of statistical significance of $5.0 \% .{ }^{18}$

Tabwin 36b, The $\mathrm{R}$ Project for Statistical Computing 3.0.2 and Microsoft Excel 2007 were used to compile and analyze data banks.

The study was approved by the Research Ethics Committee of the Aggeu Magalhães Research Center, Oswaldo Cruz Foundation, Recife, Pernambuco (Certificate No. 13161113.7.0000. 5190).

\section{Results}

The mean number of children per woman fell continuously to a rate of 1.78 in 2010 , which is lower than the rate needed to stabilize the population $(2,1)$. This tendency was accompanied by a fall in the birth rate, which decreased $28.50 \%$ between the first and the last year analyzed (Table 1 ).

According to the SIH, there were more than 32.5 million births, representing $72.42 \%$ of births occurring in the country in the whole period evaluated. Paradoxically, there was a significant decrease in vaginal births $(p<0.001)$, with an increase of $63.68 \%$ in Caesareans $(p<0.001)$ (Table 2).

Prenatal consults also saw a significant increase $(p<0.001)$, with a mean annual growth of over 28,000 women attending more than seven consults, in the public and private sectors (Table 2).

Despite the decrease in the proportion of births among mothers aged up to 19 years, the rate of pregnancy in adolescence is still high in the country (19.28\%). On the other hand, an increase was noted in the proportion of live births in the other age groups, especially the $40-49(35.03 \%)$ and $50+$ years $(175 \%)$ age brackets. A large significant increase was found in primiparous women with 40 or more years of age $(p<0.001)$, with a mean increase of 490 births per year (Table 3 ).

In case of children with Down syndrome, the largest increase was among mothers aged 40 years or over $(223.88 \%)$, a proportion 30 times greater than that found in other age groups, in 2013 (Table 4)

The proportional variation in low weight births was also higher among women of the older age group $(32.84 \%)$, while there was a significant reduction among the children of adolescents $(p<0.001)$. Prematurity was the most striking variation with a significant growing tendency in all age groups (Table 4).

The maternal mortality rate saw a mean annual reduction of 1.09 to 64.75 deaths per 100,000 live births in 2011. Child mortality rates also fell. The neonatal mortality coefficient fell from 13.49 to $9.20 / 1.000$ and perinatal mortality from 22.95 to 17.79/1000 births (Table 5).

The number of infant deaths fell significantly, however, approximately $70 \%$ were of avoidable causes, affecting more than 26,900 children in 2013. The group of causes related to adequate care during gestation and childbirth saw a significant increase $(p<0.001)$ with a proportional variation of $33 \%$ (Table 5).

Most maternal deaths were connected with direct obstetric causes, with a mean annual reduction of $0.70 \%$ in number of deaths (Table 5 ). 
General population, women of fertile age, birth rate and fecundity. Brazil, 1999 - 2013.

\begin{tabular}{|c|c|c|c|c|c|}
\hline \multirow{2}{*}{ Year } & \multirow{2}{*}{ Populatio } & \multicolumn{2}{|c|}{ Women of fertile age } & \multirow{2}{*}{$\begin{array}{l}\text { Birth } \\
\text { rate }\end{array}$} & \multirow{2}{*}{$\begin{array}{c}\text { Fecundity } \\
\text { rate }\end{array}$} \\
\hline & & $\mathbf{N}$ & $* \%$ & & \\
\hline 1999 & 163947436 & 53663899 & 32.73 & 21.86 & 2.33 \\
\hline 2000 & 169799170 & 55525740 & 32.70 & 20.32 & 2.29 \\
\hline 2001 & 172385776 & 56386231 & 32.71 & 19.49 & 2.20 \\
\hline 2002 & 174632932 & 57134205 & 32.72 & 18.73 & 2.12 \\
\hline 2003 & 176876251 & 57880352 & 32.72 & 18.23 & 2.07 \\
\hline 2004 & 179108134 & 58623425 & 32.73 & 17.88 & 2.03 \\
\hline 2005 & 184184074 & 60313460 & 32.75 & 17.47 & 1.99 \\
\hline 2006 & 186770613 & 61174428 & 32.75 & 17.00 & 1.94 \\
\hline 2007 & 189335191 & 61095856 & 32.27 & 16.60 & 1.90 \\
\hline 2008 & 189612814 & 60974994 & 32.16 & 16.26 & 1.86 \\
\hline 2009 & 191481045 & 61417666 & 32.08 & 15.98 & 1.84 \\
\hline 2010 & 190755799 & 62110637 & 32.56 & 15.78 & 1.82 \\
\hline 2011 & 192379287 & 62649609 & 32.57 & 15.63 & 1.78 \\
\hline 2012 & 193976530 & 63177694 & 32.57 & - & - \\
\hline 2013 & 201032714 & 63470428 & 31.57 & - & - \\
\hline $\begin{array}{l}\text { Proportional } \\
\text { variation }\end{array}$ & 22.62 & 18.27 & -3.54 & -28.50 & -23.61 \\
\hline B & - & - & - & -0.47 & -0.05 \\
\hline$p$ & - & - & - & $<0.001$ & $<0.001$ \\
\hline
\end{tabular}

* Proportion in relation to total population/year.

Source: Brazilian Institute of Geography and Statistics (IBGE); Interagency Health Information Network (RIPSA).

Table 2

Normal births, percentage of caesarians and prenatal consults. Brazil, 1999 - 2013.

\begin{tabular}{|c|c|c|c|c|}
\hline \multirow{2}{*}{ Year } & \multirow{2}{*}{$\begin{array}{l}\text { Normal } \\
\text { births }\end{array}$} & \multirow{2}{*}{ *\% Caesarian } & \multicolumn{2}{|c|}{ Pregnant women with 7+ prenatal consults } \\
\hline & & & $\mathbf{N}$ & $\star * * \%$ \\
\hline 1999 & 1992568 & 24.89 & 1510040 & 46.37 \\
\hline 2000 & 1906320 & 23.92 & 1401585 & 43.71 \\
\hline 2001 & 1801406 & 25.06 & 1419062 & 45.55 \\
\hline 2002 & 1753659 & 25.18 & 1463469 & 47.84 \\
\hline 2003 & 1664680 & 26.39 & 1516553 & 49.92 \\
\hline 2004 & 1626092 & 27.53 & 1573185 & 51.98 \\
\hline 2005 & 1596483 & 28.61 & 1601391 & 52.76 \\
\hline 2006 & 1498323 & 30.14 & 1606185 & 54.54 \\
\hline 2007 & 1496045 & 32.23 & 1613980 & 55.82 \\
\hline 2008 & 1334663 & 33.24 & 1672280 & 56.98 \\
\hline 2009 & 1292222 & 34.77 & 1667192 & 57.86 \\
\hline 2010 & 1237083 & 36.74 & 1733492 & 60.57 \\
\hline 2011 & 1199623 & 38.40 & 1785198 & 61.28 \\
\hline 2012 & 1132041 & 40.18 & 1792629 & 61.69 \\
\hline 2013 & 1063764 & 40.74 & 1812681 & 62.42 \\
\hline $\begin{array}{l}\text { Proportional } \\
\text { variation }\end{array}$ & -46.61 & 63.68 & 20.04 & 34.61 \\
\hline B & -64.369 & 1.29 & 28.708 & 1.38 \\
\hline$p$ & $<0.001$ & $<0.001$ & $<0.001$ & $<0.001$ \\
\hline
\end{tabular}

* Proportion in relation to total births occurring in the SUS network/year; ** Proportion in relation to total live births lyear.

Source: SIH/MS; SINASC/MS. 


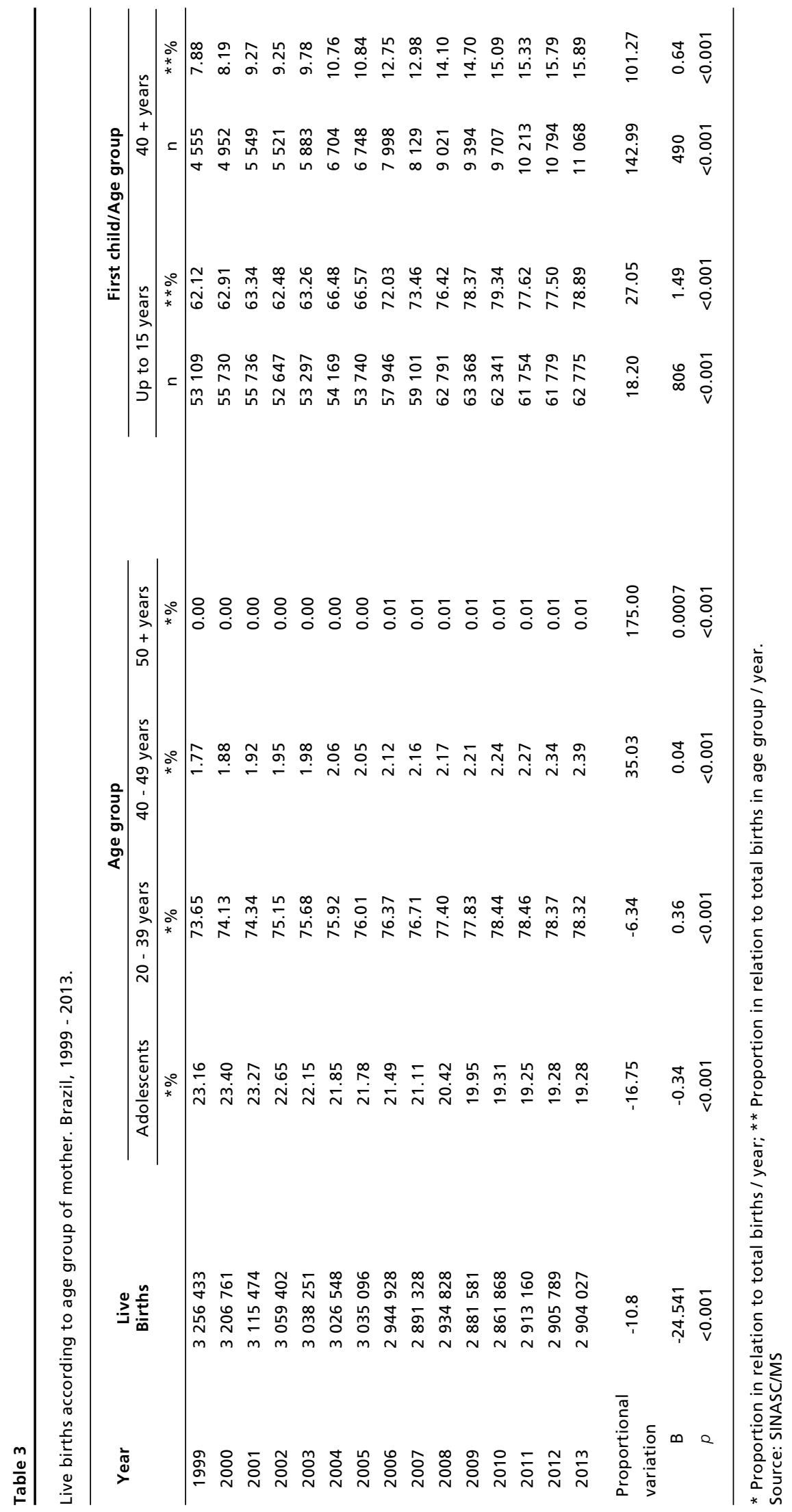


Live births with Down syndrome, low birth weight and prematurity, according to age group of mother. Brazil, 1999 and 2013.

\begin{tabular}{|c|c|c|c|c|c|c|c|}
\hline \multirow{3}{*}{ Variables } & \multirow{2}{*}{\multicolumn{2}{|c|}{1999}} & \multirow{2}{*}{\multicolumn{2}{|c|}{2013}} & \multicolumn{3}{|c|}{$1999-2013$} \\
\hline & & & & & \multirow{2}{*}{$\begin{array}{c}\text { Proportional } \\
\text { Variation }\end{array}$} & \multicolumn{2}{|c|}{ Trend } \\
\hline & $\mathrm{n}$ & $* \%$ & $\mathrm{n}$ & $* \%$ & & $\mathrm{~B}$ & $p$ \\
\hline \multicolumn{8}{|l|}{ Down syndrome } \\
\hline $10-19$ years & 27 & 0.00 & 66 & 0.01 & 144.44 & 0,7 & 0,53 \\
\hline $20-39$ years & 251 & 0.01 & 530 & 0.02 & 111.16 & 12 & 0,06 \\
\hline $40+$ years & 67 & 0.17 & 217 & 0.31 & 223.88 & 7 & 0,01 \\
\hline \multicolumn{8}{|l|}{ Low birth weight } \\
\hline $10-19$ years & 66201 & 8.78 & 53159 & 9.49 & -19.70 & -1.198 & $<0,001$ \\
\hline $20-39$ years & 170807 & 7.12 & 185570 & 8.16 & 8.64 & 1.092 & $<0,001$ \\
\hline $40+$ years & 6318 & 10.93 & 8393 & 12.05 & 32.84 & 127 & $<0,001$ \\
\hline \multicolumn{8}{|l|}{ Premature birth } \\
\hline $10-19$ years & 32841 & 4.35 & 74396 & 13.29 & 126.53 & 1480 & 0,03 \\
\hline $20-39$ years & 84034 & 3.50 & 248504 & 10.93 & 195.72 & 8184 & $<0,001$ \\
\hline $40+$ years & 2618 & 4.53 & 10548 & 15.14 & 302.90 & 412 & $<0,001$ \\
\hline
\end{tabular}

* Proportion in relation to total number of births in age group /year. Source: SINASC/MS

\section{Discussion}

In the fifteen years studied, almost $3 / 4$ of all births occurred within the SUS network. There was a substantial increase in caesarian sections in this sector. Rates far higher than the maximum of $15 \%$ recommended by the WHO means that Brazil leads the world ranking in terms of surgical births. This is a critical and challenging state of affairs for childbirth care.

With the highest prevalence of caesarian births in the world (56.7\%), 19 Brazil is followed by Turkey (50.4\%), Mexico (45.2\%), Chile (44.7\%) and compares unfavorably with much lower rates in Denmark $(22.2 \%)$, Sweden (16.4\%) and the Netherlands $(15.6 \%){ }^{20}$

The technocratic care model overvalues medical technology and the medicalization and hospitalization of childbirth and, although births are still predominantly vaginal in the public sector, "care is excessively ritualistic and interventionist and not based on scientific evidence". 21

The number of births fell over the fifteen years evaluated, although the rate of adolescent pregnancy is still high. Among women aged 40 years or older, primiparous pregnancies increased more than $100 \%$, indicating that women are putting off the birth of the first child in the country.

In this age group, age is an independent risk factor for placenta praevia, premature detachment of placenta, caesarian birth and perinatal mortality, including stillbirth. The role of routine prenatal surveillance among these women thus requires more in-depth investigation. 22

Down syndrome was more frequent among the children of women aged 40 years or over, along with low birth weight (LBW), which exceeded the $10 \%$ acceptable according to the World Declaration on the Survival, Protection and Development of the Child.23 Premature birth saw a marked increase among mothers of all age groups. These factors pose a direct risk of morbidity, mortality and underdevelopment in children.

The birth of children with low weight is associated with low quality and inequality in prenatal care, excessive medical interventions and the increase in premature birth. Prevention of premature birth requires adequate and timely prenatal care and control of caesarian sections without technical indication. $2,3,23,24$

The significant growth in the number of prenatal consults identified in the study reveals the expansion of access to care during gestation. However, studies have shown that, despite high coverage, prenatal care is of unsatisfactory quality and thus compromises the prevention, diagnosis and treatment of mothers and babies. $12,25,26$

The reduction in neonatal and perinatal deaths 


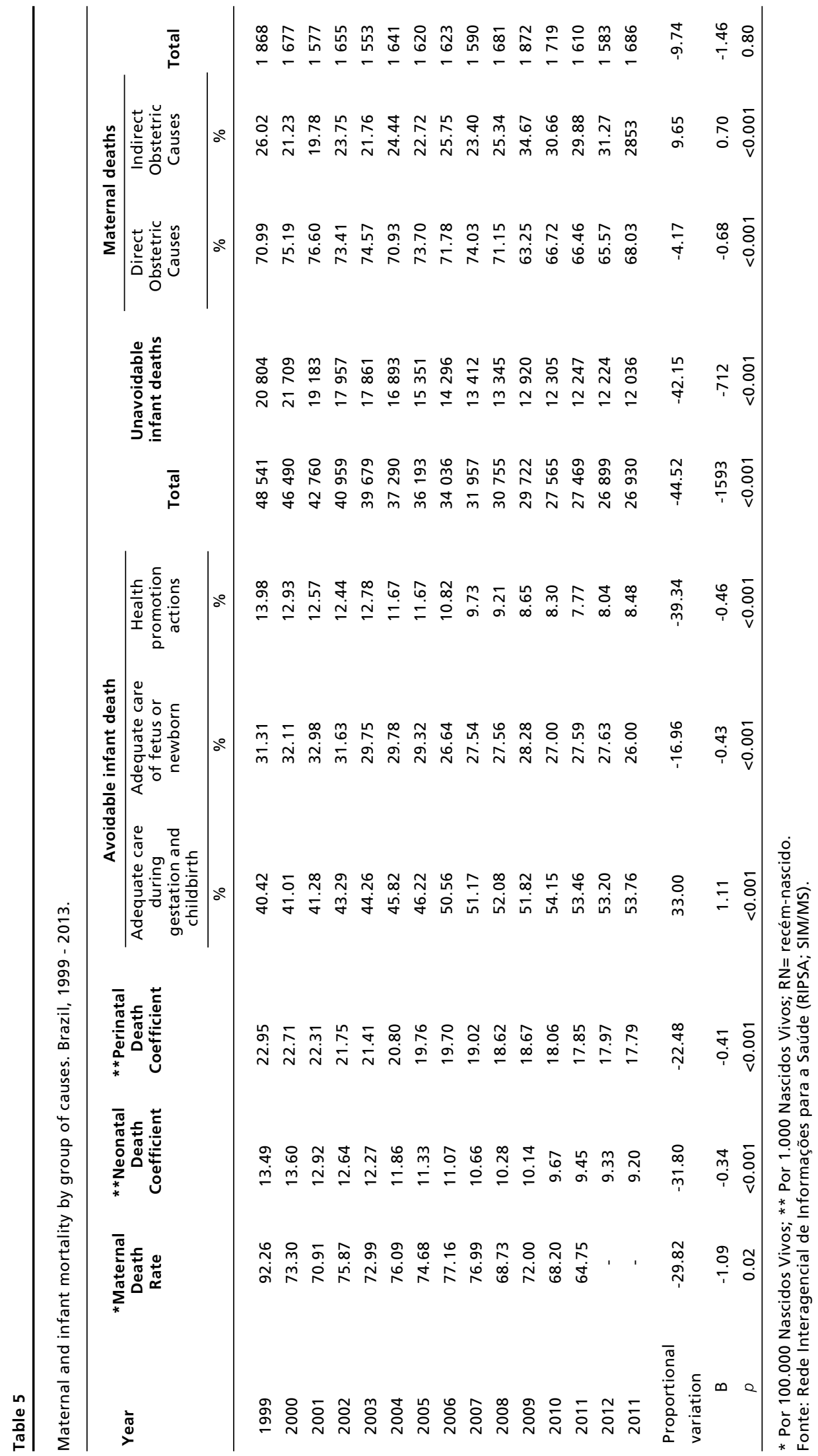


occurred gradually at a rate of around 0.3 deaths/ 1,000 live births per year. There was also an increase in avoidable causes of infant death related to adequate care during gestation and childbirth. The slow decrease in neonatal deaths compared to the substantial reduction in infant mortality points to a lack of integration between prenatal care and childbirth and high rates of, often unnecessary, caesarian births. The predominance of causes of death preventable by adequate care during gestation and childbirth shows the need to improve care during these periods. 5,27

The maternal death rate remained persistently high and most deaths were related to direct obstetric causes, principally hypertension and hemorrhage, which are mostly preventable with prenatal supervision and childbirth care and high quality birth. This suggests shortcomings in terms of the adequacy and quality of obstetric care, from the prenatal period to immediate postpartum. 27 Around the world in the past decades, maternal mortality has decreased at a much faster rate than that observed in Brazil. Countries where such deaths are at acceptable levels, according to the WHO classification, the causes of death are predominantly indirect. $6,28,29$

The results of the present study point out potential problems regarding the quality of hospital and prenatal obstetric care, since an increase in coverage of these has occurred simultaneously with a rise in infant deaths preventable by adequate care during gestation and childbirth, in premature births, low weight, and Down syndrome, and an unchanged maternal mortality rate for direct obstetric causes.

In the fifteen years studied, there were major changes, which show that the critical situation regarding the childbirth care model in Brazil has still not been resolved and still poses a serious challenge. The technocratic model of childbirth care is still hegemonic despite changes observed in the profile of mothers and births, with a gradual reduction in perinatal and neonatal deaths and a continuingly high maternal mortality rate. This shows that the system needs to be designed in such a way as to solve old problems and meet new demands, directing efforts to ensuring care that guarantees the right to safe and healthy childbirth.

\section{References}

1. Moreira MEL, Gama SGN, Pereira APE, Silva AAM, Lansky S, Pinheiro RS, Gonçalves AC, Lea MC. Práticas de atenção hospitalar ao recém-nascido saudável no Brasil. Cad Saúde Pública. 2014; 30 (Supl): S128-S139.

2. Leal MC, Pereira APE, Domingues RMSM, Theme Filha MM, Dias MAB, Nakamura-Pereira M, Bastos MH, Gama SGN. Pesquisa Nascer Brasil: Intervenções obstétricas durante o trabalho de parto e parto em mulheres brasileiras de risco habitual. Cad Saúde Pública. 2014; 30 (Supl. 1): S17-S47.

3. Lansky S, Friche AAL, Silva AAM, Campos D, Bittencourt SDA, Carvalho ML, Frias PG, Cavalcante RS, Cunha AJLA. Pesquisa Nascer Brasil: Perfil da mortalidade neonatal e avaliação da assistência à gestante e ao recémnascido. Cad Saúde Pública. 2014; 30 (Supl. 1): S192S207.

4. Carneiro RG. Cenas de parto e políticas do corpo. Rio de Janeiro: FIOCRUZ; 2015. 328p.

5. Santos HG, Andrade SM, Silva AMR, Mathias TAF, Ferrari LL, Mesas AE. Mortes infantis evitáveis por intervenções do Sistema Único de Saúde: comparação de duas coortes de nascimentos. Ciênc Saúde Coletiva. 2014; 19 (3): 907-16

6. Souza JP. Mortalidade materna e desenvolvimento: a transição obstétrica no Brasil. Rev Bras Ginecol Obstet. 2013; 35 (12): 533-5.

7. Brasil. Ministério da Saúde. Secretaria de Vigilância à Saúde. Departamento de Análise de Situação de saúde. Guia de vigilância epidemiológica do óbito materno. Brasília; 2009.
8. Malta DC, Duarte EC, Almeida MF, Dias MAF, Neto OLB, Ferraz W, Souza MFM. Lista de causas de mortes evitáveis por intervenções do Sistema Único de Saúde do Brasil. Epidemiol Serv Saúde. 2007; 16 (4): 233-44.

9. Brasil. Ministério da Saúde. Secretaria de Vigilância em Saúde. Secretaria de Atenção à Saúde. Manual de vigilância do óbito infantil e fetal e do Comitê de Prevenção do Óbito Infantil e Fetal. Brasília, DF; 2009.

10. Pontes, MGA, Lima GMB, Feitosa IP, Trigueiro JVS. Parto nosso de cada dia: um olhar sobre as transformações e perspectivas da assistência. Rev Ciênc Saúde Nova Esperança. 2014; 12 (1): 69-78.

11. Silva ALA, Mendes ACG, Miranda GMD, Sá DA, Souza WV, Lyra TM. Avaliação da assistência hospitalar materna e neonatal: índice de completude da qualidade. Rev Saúde Pública. 2014; 48 (4): 682-91.

12. Radis, Comunicação e Saúde: acesso e humanização, direitos da mãe e do bebê. Editora FIOCRUZ, 2012; 117. Retrieved from http://www6.ensp.fiocruz.br/radis/sites/ default/files/117/radis_117.pdf

13. Organización Panamericana de La Salud (OPAS). Resúmenes metodológicos en epidemiología: análisis de la situación de salud. Boletín Epidemiológico, Washington, Organización Panamericana de la Salud; 1999. p. 1-3.

14. Lima CRA, Schramm JMA, Coeli CM, Silva MEM. Revisão das dimensões de qualidade dos dados e métodos aplicados na avaliação dos sistemas de informações em saúde. Cad Saúde Pública. 2009; 25 (10): 2095-2109. 
15. Mota E, Carvalho DMT. Sistemas de Informação em Saúde. In: Rouquayrol MZ, Almeida Filho N (Org.) Epidemiologia e Saúde. Rio de Janeiro: MEDSI; 2003. cap 21. p. $605-28$

16. IBGE (Instituto Brasileiro de Geografia e Estatística). Diretoria de pesquisas. Coordenação de população e indicadores sociais. Gerência de estudos e análises da dinâmica demográfica. Projeção da população do Brasil por sexo e idade para o período 2000 - 2060. [accessed 20 Oct. 2015] Retrieved from http://tabnet.datasus.gov.br/cgi/ deftohtm.exe?ibge/cnv/projpopbr.def

17. RIPSA (Rede Interagencial de Informação para a Saúde). Indicadores e Dados Básicos para a saúde no Brasil 2012. [accessed 5 Oct. 2015]. Retrieved from http://tabnet.datasus.gov.br/cgi/idb2012/matriz.htm

18. Montgomery DC, Jennings CL, Kulachi M, editors. Introduction to Time Series Analysis and Forecasting. 1 ed. New Jersey: John Wiley \& Sons; 2008.

19. Brasil. Ministério da Saúde. Sistema de Informações sobre Nascidos Vivos. 2015. [accessed 20 Oct. 2015]. Retrieved from http://tabnet.datasus.gov.br/cgi/tabcgi.exe?sinasc/cnv/ nvuf.def

20. Organization for Economic Co-operation and Development. Health at a glance 2015. Paris: OECD Publishing; 4 Nov. 2015.

21. Oliveira MIC, Dias MAB, Cunha CB, Leal MC. Qualidade da assistência ao trabalho de parto pelo Sistema Único de Saúde, Rio de Janeiro (RJ), 1999-2001. Rev Saúde Pública. 2008; 42 (5): 895-902.

22. Padilha JF, Torres RPP, Gasparetto A, Farinha LB, Mattos KM. Parto e idade: características do Estado do Rio Grande do Sul. Rev Saúde. 2013; 39 (2): 99-108.

Received on december 14, 2015

Final version submitted on march 14, 2016

Approved on april 7, 2016
23. Organização das Nações Unidas (ONU). Declaração Mundial sobre a Sobrevivência, a Proteção e o Desenvolvimento da Criança. Nova Iorque: ONU; 1990.

24. Capelli JCS, Pontes JS, Pereira SEA, Silva AAM, Carmo CN, Boccolini CS, Almeida MFL. Peso ao nascer e fatores associados ao período pré-natal: um estudo transversal em hospital maternidade de referência. Ciênc Saúde Coletiva. 2014; 19 (7): 2063-72.

25. Anversa ETR, Bastos GAN, Nunes LN, Dal Pizzol TS Qualidade do processo da assistência pré-natal: unidades básicas de saúde e unidades de Estratégia Saúde da Família em município no Sul do Brasil. Cad Saúde Pública. 2012; 28 (4): 789-800.

26. Domingues RMSM, Hartz ZMA, Dias MAB, Leal MC. Avaliação da adequação da assistência pré-natal na rede SUS do município do Rio de Janeiro, Brasil. Cad. Saúde Pública. 2012; 28 (3): 425-37.

27. Barros FC, Matijasevich A, Requeio JH, Giugliani E, Maranhão EG, Monteiro CA, Barros AJD, Bustreo F, Merialdi M, Victora CG. Recent Trends in Maternal, Newborn, and Child Health in Brazil: Progress Toward Millennium Development Goals 4 and 5. Am J Public Health. 2010; 100 (10): 1877-89.

28. Szwarcwald CL, Escalante JJC, Rabello Neto DL, Souza Jr. PRB, Victora CG. Pesquisa Nascer Brasil: Estimação da razão de mortalidade materna no Brasil, 2008-2011. Cad Saúde Pública. 2014; 30 (Supl. 1): S71-S83.

29. Laurenti R, Mello Jorge MH, Gotlieb LD. Mortes por doenças infecciosas em mulheres: ocorrências no ciclo gravídico-puerperal. Rev Assoc Med Bras. 2009; 55 (1): $64-9$ 